OSU WPL 34 (1986) 123-126

\title{
The Etymology of bum: Mere Child's Play*
}

\author{
Mary E. Clark \\ The Clintonville Academy \& Otterbein College \\ and \\ Brian D, Joseph
}

The etymology of the word bum in the meaning 'buttocks, bottom' is generally considered to be uncertain (e.g. by OED: s.v., by onions et al. (1966: s.v.), and others).1 One of the leading possibilities, though, is that bum is somehow a contraction of bottom (so Century Dictionary \& Cyclopedia (1906: s.v.), Partridge (1966: s.v.), Morris and Morris (1977: s.v.)). This etymology has been denied, however, by the OED for two reasons: phonetic difficulties in the development from bottom to bum and the "historical fact that 'bottom' in this sense is found only from the 18th cent." (p. 1173), while bum, in its Middle English form bom, occurs as early as the 14th century (in Trevisa Higden Rolls, from 1387 ). ${ }^{2}$

There is little to say about the attestation question; we note only that attestation is often merely a matter of chance and it is quite possible that bottom referring to 'buttocks' might have been omitted from Middle English texts now available for reasons other than its nonoccurrence in the usage of time. 3 Also, the shift in meaning from 'bottom (in general)' to 'bottom part of a seated person' seems natural enough to have been able to have occurred independently at several times in the history of English. 4

The phonetic "difficulties", however, can be dealt with, and it is that side of the etymological connection of bottom with bum that we wish to address here. It seems that the main objection to the phonetic derivation of bum from bottom stems from the fact that such a reduction or contraction was not a regularly occurring process in the historical phonology of English. In particular, bottom has continued into Modern English alongside bum, giving the current doublet, and there are words with a similar phonetic shape which have not undergone this "reduction", such as bottle and bodice, both attested early enough in English to be relevant to the matter at hand. ${ }^{5}$ Thus if bum is derived in some way from bottom, it would have to have arisen in a dialect other than the one(s) providing the main input into standard Modern English.

A solution to these difficulties was suggested to us through observation of the usage of our older son David. At the age of 2 years 4 months (in late 1982), we heard David, while being diapered, say [ba(?)2m], with a clear reference to the part of his anatomy we were most concerned with, i.e. his bottom. The glottal stop was somewhat weakly articulated, so that it was almost absent to our ears, and in fact later repetitions of the word may not have even contained it (hence the parentheses in our transcription). The resulting utterance sounded remarkably like adult bum. Moreover, the process responsible for the reduction evident in David's pronunciation of bottom seems to have been a regular one in his speech at that time. ${ }^{6}$ During approximately the same period in his development, we heard [bawal] for bottle, [1I.21] for little, and [pखmbeyər] for Paddington Bear (with assimilation of $\underline{n}$ to $m$ ), all with a medial dental stop "reduced" and the resulting word "contracted", with some alteration of the vowels, when compared with the adult version. The regularity of this process in David's speech is shown also by the fact that at a later stage of development, 2 years 10 months, all of the above words which 
had appeared in "reduced" form six months earlier came to have a medial dental stop in them.

Thus it is evident that there are "dialects"--or, more accurately, sociolects-in which the phonetic reduction of bottom to something like bum is perfectly regular. We propose, then, that adult English bum has its origins in child speech, especially in the relatively early stages of its acquisition. The occurrence of bum in adult English would then result from a form of dialect borrowing, fostered by the opportunity for close and frequent adult-child interaction that diapering provides. The parent would thus be using and incorporating into his/her own speech a true child language form.

As with any borrowing-dialect or otherwise--or neologism, the entry of bum from child language into adult speech needs only to have occurred once, though the possibility of recurring borrowing at several points in the history of English cannot be discounted. 8 Once a part of the mainstream dialect, the retention and spread of this word becomes a matter not of dialect borrowing but instead of the regular lineal transmission of langauge through subsequent generations. However, one interesting aspect to this proposed borrowing--whether it occurred once or many times--is that it is entirely in keeping with the Neogrammarian view of sound change, in which dialect borrowing can be an explanation for apparently irregular sound changes in a given speech community. Here the donor dialect--child language--had the phonetic reduction regularly and the borrowing into adult language led to the bum/bottom doublet and the seemingly irregular and sporadic sound change linking the two.

Moreover, parallels can be found for the type of development suggested here for bum. The word tummy, for instance, is universally accepted (e.g. by OED, the American Heritage Dictionary, Partridge, etc.) as being in origin a nursery form or infantile alteration of stomach; its use by.adults is especially common when they are talking to children, but it has penetrated into adult speech sufficiently to form the basis for a product name (Tums) and advertising slogan (Tums for the tummy). Similarly, bye-bye, as observed by Dilkes 1983 , is another nursery word--here probably an adult conventionalized child form rather than a form originating with children--which has made its way into adult use.

\section{Notes}

* we would like to thank Zheng-Sheng Zhang of the Department of Linguistics of the Ohio State University for his help with some of the research on this paper.

1. Some sources venture no opinion at all; Webster's 3rd, for example, has no comment on the etymology of this word.

2. The actual citation with the one attestation runs thus:

He hadde many 3 ere $\bar{p}$ e evel 7 at hatte ficus, 7 at is a schrewed evel, for it semep pat his bom is oute pat hap pat evel. 
This is apparently the only Middle English occurrence of bom; for both the MED and the OED list only this lone example.

3. It is possible that the OED was somewhat precipitate in its pronouncement that bottom meaning 'buttocks' dates only from the 18th century. We suspect that in A Midsummer Night's Dream (1595), the name of character Bottom may be pert of an elaborate Shakespearean pun which plays upon a meaning of 'buttocks' for common noun bottom. In the first place, Bottom is given the head of an ass (donkey); with the contemporary (American) senses of Bottom and Ass, i.e. bottom = 'buttocks' and ass ='but tocks; donkey', there is a reasonably good pun playing on Bottom's name and his fate. The double sense of ass, though, is the result of a sound change merging ass 'donkey' with the ME and ENE arse 'buttocks' through the loss of preconsonental $\underline{r}$ (with some vowel changes as well, most likely). However, there is a strong possibility that arse had an $\underline{r}$-less pronunciation as early as Shakespeare's time. Barber (1976: 319) points out that $" / r /$ was lost in some non-standard forms of speech in IME, especially in eastern dialects and in substandard London speech ... before $/ s /$ and $/ 5 / /^{\prime \prime}$. For example, Barber continues, "in Troilus and Cressia, Shakespeare uses the word tercell "a male hawk' [while] in Romeo and Juliet, the same word occurs in the form tassell". Both $r$-ful and $r$-less forms of arse are likely to have coexisted in Shakespeare's time, increasing the possibility of a play on arse/ass. Now, according to Rowse (1978: I.232), Bottom's name is already to be understood as a pun on his occupation as a weaver, bottom referring to "a skein on which the weaver's thread is wound" (and we note also that weavers of necessity spend a lot of time sitting); it therefore is not unreasonable to suggest that Shakespeare, as an ardent and of ten ribald punner, may have intended a double pun, pivoting on the relationship between Bottom's name and his identity with ass ( $=$ 'donkey' and 'buttocks'). Diagrammatically, then, the relations in these puns are:

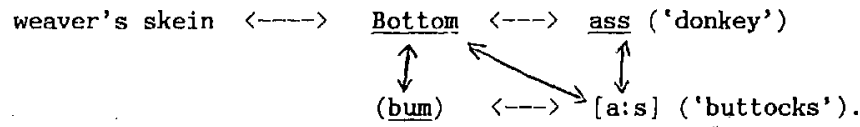

The success of these puns depends on a meaning of 'buttocks' for both bottom and ass (through the near-homonym in the nonstandard pronunciation of arse). Thus we conclude that the meaning 'buttocks' for bottom was available somewhat earlier than the OED suggests, at least as early as the late 16 th century.

4. David Stampe of the Department of Linguistics of University of Hawaii has informed us that he has found virtually the same semantic connection in the Munda languages of India that he has worked with, adding plausibility to our claim that it is indeed a natural connection. We note also that anong the meanings given for Middle English botme in the MED are several from which a shift to the meaning 'buttocks' would be fairly straightforward; especially relevant are the meanings 'the part of a bodily organ farthest from the exterior; bottom of the stomach' (p. 1077).

5. The putative "reduction" involves elimination of the medial consonant as well as alteration of the vowels. The source we propose below addresses both of these matters. 
6. We know of several other mothers who have also noted a similar pronunciation of bottom from their children, making it likely that such a reduction is characteristic of children's speech in general.

7. We hesitate to label this stop, for it is unclear to us whether the input to David's speech included a $/ t /, / d /$, or flap $/ D /$ in these words.

8. This is especially true if the reduced form is a common child language pronunciation; see footnote 6 .

\section{References}

American Heritage Dictionary of the English Language. (1978). Wm. Morris, ed., Boston: Houghton-Mifflin Co.

Barber, C. (1976). Early Modern English. London: Andre Deutsch.

The Century Dictionary and Cyclopedia. (1906). New York: The Century Co.

Dilkes, M. (1983). "Bye-bye", American Speech 58.92.

MED = Middle English Dictionary. (1956). H. Kurath \& S. Kuhn, eds'. Ann Arbor: University of Michigan Press.

Morris, W. \& M. Morris. (1977). Dictionary of Word and Phrase Origins. New York: Harper and Row.

OED $=$ The Oxford English Dictionary. (1961). J. Murray, et al., eds., Oxford, at the Clarendon Press.

Onions, C. T., G. W. S. Friedrichsen, \& R. W. Burchfield, eds. (1966). The Oxford Dictionary of English Etymology. Oxford at the Clarendon Press.

Partridge, E. (1966). Origins: A Short Etymological Dictionary of Modern English. New York: MacMillan.

Rowse, A. L. (1978). The Annotated Shakespeare. New York: Clarkson N. Potter, Inc., Publishers.

Webster's 3rd = Webster's Third New International Dictionary of the English Language Unabridged. (1966). Springfield: G, \& C. Merriam Co. 